Sen. L. R. Bolter purchased the town lots and removed the scattered buildings. The little schoolhouse remained in use until 1916, but it too has since disappeared. Only memories remain.

\title{
References
}

Biographical History of Harrison County, Iowa. Chicago: National Publishing Co., 1891.

Hunt, C. W. and Clark, W. L., History of Harrison County, Iowa. Indianapolis: B. F. Bowen \& Co., Inc., 1915.

Smith, Joe H., History of Harrison County, Iowa. Des Moines: lowa Printing Co., 1888.

\section{THE MISSOURI RIVER IMPROVEMENT PROGRAM}

\author{
by George R. Call \\ Sioux City, lowa
}

The following article is composed of excerpts from Mr. Call's manuscript, "The Missouri River Program as I Knew It," which is on file at the Iowa State Historical Library. Both Mr. Call, an Honorary Life Member and Director of the Mississippi Valley Association, and his father, George C. Call, were instrumental in establishing and maintaining the program.

When the pioneers were migrating into the Missouri River Valley, pilots of the new stern wheel boats found that the unimproved Missouri River was full of snags, rocks and other obstacles. Many boats were sunk and many lives were lost. No money was available at the time for the removal of the hazards from the river; there were hardly enough settlers in the Valley to warrant much more than protection from the marauding Indians. However, settlers seemed determined to come into the productive area. The river must be made navigable. The two requirements of a navigable river are that it provide a channel of suitable depth and width and that its water supply be regulated.

Businessmen and other leading citizens recognized the need for improving the Missouri River early in the 20th century. President Theodore Roosevelt responded to the need 
by calling a conference in Washington, D.C. in May 1908 to discuss the more general topic of the utilization of natural resources. Governors from all the states were invited and requested to bring with them two other representatives. The meeting, held in the East Room of the White House, was well attended. Representing Iowa were its governor, Albert B. Cummins, and two men from Sioux City, A. B. Beall and George C. Call.

The activities and resolutions of the convention resulted in the unanimous support of a program for appropriations to improve natural resources. The National Rivers and Harbors Congress was expanded and developed into one of the largest lobbies, with the added purpose of bringing to the attention of the U. S. Congress the needs of adequate finances for rivers and harbors, the improvement of rivers, and the development of other natural resources of the nation. Both Call and Beall became active members of the association. Subsequent meetings of the National Rivers and Harbors Congress, which were always held in Washington, found these two men in regular attendance.

Call and Beall returned to Sioux City from the 1908 meeting determined to do something for their community and the Missouri River; they lost no time. Within a month they had publicized the great need for help at the grass roots and had proposed a convention, to be called the "Missouri River Navigation Congress."

Both men felt that the first meeting should be held in Sioux City. Realizing the need of some organized backing, they went before the city's Real Estate Association, which agreed to act as sponsor. Call, Beall and J. L. Kennedy were appointed as a committee, and invitations were sent out to key political figures and other influencial men in various cities and towns in the Valley, from Kansas City, Mo. to Fort Benton, Mont. Among those who attended the first meeting were such notables as the governor of Iowa, the Hon. A. B. Cummins; the governor of Nebraska, the Hon. George L. Sheldon; the governor of North Dakota, the Hon. John Burke; the governor of South Dakota, the Hon. Cole I. Crawford, and several members of Congress from nearby districts. They 
discussed (1) the duty of the U. S. Congress to adopt a broad and comprehensive plan to conserve and utilize natural resources, (2) the need for improvement of rivers, (3) the construction of the Panama Canal and (4) the part the railroads would play in the development of transportation, whether rivals or friends.

Although a year and a half had passed and some of the enthusiasm had dwindled, there was destined to be another meeting of the Missouri River Navigation Congress. It was called the "Second Annual" and was held in Yankton, S.D. in July 1909. Support for the organization died, and the "Third Annual" never came into being.

It was apparent however, that some concentrated planning must be made on behalf of the mid-continent waterways, for the National Rivers and Harbors Congress had chosen to give its attention to the improvement of coastal harbors and rivers adjacent to the deep-water ports. Iowa representatives had, accordingly, withdrawn their memberships from the Congress.

The lack of representation in an organized body and the economic effect of the Panama Canal (1913) stimulated the development of the Mississippi Valley Association. After a delay caused by the national effort required during World War I, in 1919 a small group of men led by such distinguished citizens as Stewart Gilman, A.B. Beall, George C. Call, F. L. Eaton, and John H. Kelly, all of Sioux City, together with J. C. Nicols and other representatives from Kansas City and Omaha, Neb., called a meeting in St. Louis, Mo. It was here that the Mississippi Valley Association was formed. Its purpose was to look after the interests of the central states. The Association was made up of men from approximately 20 states in the region lying between the Rocky and Alleghany Mountains and from the Great Lakes on the north to the Gulf of Mexico on the south.

Throughout the 1920s there was general approval for the establishment of a number of upper Missouri River small main stem dams that could hold back water for eventual discharge to aid navigation. During this period to the beginning of World War II, Sioux City sent one or two private Pullman cars of delegates to the annual meetings of the Mississippi 
Valley Association at St. Louis. These many delegates from Sioux City, paying their own expenses, contributed a powerful political voice to support appropriations from the Congress for Missouri River improvement near their city. One of Sioux City's spokesmen, John C. Kelly, was honored for his outstanding work by being elected President and later Chairman of the Board of the Mississippi Valley Association.

The Missouri River had been divided into two sections for the purpose of development: Sioux City to Kansas City, and $Y$ ansas City to the mouth. Most appropriations were allocated to the southern section. As a consequence, the Upper Missouri River Association was established in 1937. It was composed of representatives from South Dakota, Nebraska and Iowa.

The disbanding of the W.P.A. and the beginning of World War II brought most river improvements to a standstill. Work was discontinued while the Missouri River flowed with only a four foot draft. Navigation was also hampered by the many "cut-offs," split channels and cross-overs.

However, some government officials remained aware of the problem. Through their efforts, they secured the recommendation for new projects from various government departments, including the Bureau of Reclamation, the Office of Indian Affairs, the Chief of Engineers of the War Department, the Department of Agriculture, and the Bureau of Fish and Wildlife Service of the Department of the Interior. The composite request from the official agencies was presented by Sen. Joseph C. O'Mahoney of Wyoming in April 1944 as Senate Document 191 in the 78th Congress. It was entitled "Missouri River Basin, the Conservation, Control and Use of Water Resources." The report was all inclusive and covered the states of Montana, Wyoming, Colorado, North Dakota, South Dakota, Nebraska, Kansas, Iowa and Missouri. The report emphasized the complexity with which the overall plan of Missouri improvements was envisioned.

By Executive Order, the Corps of Engineers of the War Department and the Bureau of Reclamation of the Department of the Interior selected two persons who were charged with merging the various plans submitted by the departments and 
told to come up with a workable composite. Brig. Gen. Lewis A. Pick of "Burma Road" fame was chosen as the officer from the Corps and W. G. Sloan, then regional engineer for the Bureau of Reclamation, was selected by the Department of the Interior. The merger of the Bureau and the Corps has been facetiously referred to as a "shotgun wedding." The "marriage" produced the Pick-Sloan Plan, upon which most of the actual physical work on the Missouri River has been based since 1947 .

Among the proposals of the Pick-Sloan Plan was a review of the needed facilities for the completion of a nine foot channel from the mouth of the Missouri River to Sioux City. It proposed the additional extension of navigation above Sioux City as far as it could be justified. It also suggested a comprehensive study of the physical condition of the land in the upper reaches of the Missouri Valley and the construction of main stem dams that would be necessary for its successful operation. The proposal was for six main stem multiple-purpose dams from Fort Peck, Mont., to Sioux City. These included the dam at Garrison, N.D.; the Oahe Dam, about eight miles north of Pierre, S.D.; Big Bend Dam; and another at Pickstown, S.D., known as Fort Randall. Farthest south was a dam to be located in the vicinity of Yankton, S.D., at a place referred to as Gavin's Point. The plan also included over 100 dams to be built on the various tributaries.

Also important were the proposals of the Department of the Interior included in the Pick-Sloan Plan for the estabishment of large irrigation districts. One of the largest proposed districts was an approximately 600,000 acre tract of land on the west bank of the James River in South Dakota.

Under the present act of Congress, the Missouri River navigation channel from St. Louis to Sioux City has been authorized to have a minimum of 300 foot width and a minimum nine foot depth. The needed discharge from the upper Missouri River dams has been estimated at approximately 30,000 cubic feet per second. In the year ending June 30, 1965 total output from the Missouri Basin System was 8.9 billion kilowatt hours. The output will increase to an estimated 11 billion kilowatt hours a year. 
There are two major types of construction from the mouth of the Missouri River to Glasgow, Mont. The first, from the mouth to Sioux City, is free-flowing with about 760 miles ( 1960 figure) of minimum width and depth. There will be no dams or obstructions in this reach of the river. The second phase, above Sioux City to the head waters, is to be a different type of construction, and the area above Yankton will be impounded with six main stem dams. When the lakes behind these dams are filled to capacity, there will be maintained about 1,000 miles of slack water above Sioux City. These "up river dams" will not only give sufficient water to maintain the desired flow for navigation purposes but will also be able to impound the surplus flood waters so that the flat river lands of the Missouri River Basin will be protected.

\begin{tabular}{|c|c|c|c|c|}
\hline \multicolumn{5}{|c|}{$\begin{array}{c}\text { Missouri River Main Stem Reservoir System } \\
\text { (April 1965) }\end{array}$} \\
\hline \multicolumn{5}{|c|}{$\begin{array}{ccc} & \text { Gross } & \\
& \text { Storage } & \\
\text { Estimated } & \text { Capacity in } & \\
\text { Total Cost } & 1,000 & \\
(\$ 1,000) & \text { acre-feet } \quad \text { Function }\end{array}$} \\
\hline Fort Peck & 158,150 & 19,400 & $\begin{array}{l}\text { FC-I-N- } \\
\text { P-R-F }\end{array}$ & Essen. Com. \\
\hline Garrison & 291,000 & 24,500 & $\begin{array}{l}\text { FC-I-N- } \\
\text { P-R-F }\end{array}$ & Essen. Com. \\
\hline Oahe & 355,000 & 23,600 & $\begin{array}{l}\text { FC-I-N- } \\
\text { P-R-F }\end{array}$ & Under Constr. \\
\hline Big Bend & 122,000 & 1,900 & FC-P-R-F & Under Constr. \\
\hline Fort Randall & 194,900 & 6,100 & $\begin{array}{l}\text { FC-N-P- } \\
\text { R-F }\end{array}$ & Essen. Com. \\
\hline Gavin's Point & 48,400 & 540 & $\begin{array}{l}\text { FC-N-P- } \\
\text { R-F }\end{array}$ & Complete \\
\hline $\begin{array}{r}{ }^{\circ} \mathrm{FC}=\text { Flood } \\
\qquad \mathrm{R}=\mathrm{R}\end{array}$ & $\begin{array}{l}\text { ontrol } \mathrm{I}= \\
\text { eation } \mathrm{F}=\end{array}$ & $\begin{array}{l}\text { Irrigation } N \\
=\text { Fish and } \mathrm{W}\end{array}$ & $\begin{array}{l}\mathrm{J}=\text { Navigatic } \\
\text { ildlife Conse }\end{array}$ & $\begin{array}{l}\mathrm{P}=\text { Power } \\
\text { rvation }\end{array}$ \\
\hline
\end{tabular}


Copyright of Annals of Iowa is the property of State of Iowa, by \& through the State Historical Society of Iowa and its content may not be copied or emailed to multiple sites or posted to a listserv without the copyright holder's express written permission. However, users may print, download, or email articles for individual use. 